\title{
Role of different planting techniques in improving the water logging tolerance and productivity of sesame (Sesamum indicum L.)
}

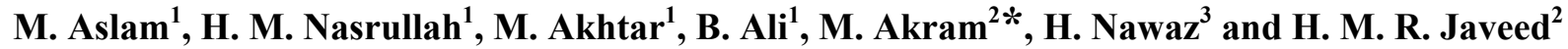 \\ ${ }^{1}$ Agronomic Research Station, Regional Agriculture Research Institute, Bahawalpur, Pakistan. \\ ${ }^{2}$ Department of Environmental Sciences, COMSATS Institute of information Technology, Vehari, Pakistan. \\ ${ }^{3}$ Department of Agronomy, University College of Agriculture, Bahauddin Zakariya University, Multan, Pakistan.
}

\begin{abstract}
Sesame is a well known oil seed crop in arid and semiarid region of Pakistan and its productivity is affected due to sensitiveness to water logging in the root zones. The experiment was conducted at research area of Agronomic Research Station, Bahawalpur during the year 2010 and 2011. The crop was sown by three different planting techniques i.e. flat sowing with $45 \mathrm{~cm}$ apart rows, ridge sowing with $45 \mathrm{~cm}$ apart, bed sowing with $60 / 30 \mathrm{~cm}$ i.e. $60 \mathrm{~cm}$ wide beds with $30 \mathrm{~cm}$ furrow between the beds. The data revealed that maximum number of plants wilted in flat planting as compared to other methods of planting were taken in this experiment. It was also recorded that bed planting at $90 \mathrm{~cm}$ apart beds gave maximum grain yield of $843 \mathrm{~kg}$ ha- 1 followed by ridge planting (seed spreading by broadcast and with augmented furrows) with a grain yield of $811 \mathrm{~kg}$ ha- 1 . The lowest yield was obtained from conventional method of sowing which gave $349 \mathrm{~kg}$ ha- 1 grain yield. Water logging stress in the root zone can successfully be avoided by planting sesame on beds or ridges under climatic conditions of Bahawalpur.
\end{abstract}

Keywords: Bed and flat planting; Water logging stress; Sesamum indicum L

\section{Introduction}

The sesame crop is very sensitive to a biotic stress like water logging and is grown in the arid and semiarid region of the province Punjab of Pakistan. The productivity of crop is severely affected due to water logging condition in the irrigated areas. Under specific weather conditions, certain diseases like Fusarium wilt also attack the crop plants after irrigation when water comes in direct contact to the stems of plants that may become more severe in future (Smith et al. 2000). The crop is irrigated by direct flooding method so it causes the severe plant wilting during plant growth stages and some varieties are very susceptible to Fusarium wilt that even causes $80 \%$ yield loss.

Generally, the crop is sown on flat field and is irrigated through flood irrigation so a considerable number of plants get wilted and ultimately die due to water logged conditions. According to Mensah et. al., (2006) both flooding and drought resulted in stunted growth, reduced dry matter and poor seed yield per plant. Prolonged flooding reduced the maturity time, and induced chlorosis and floral abortion. The growth and seed yield of sesame are adversely affected by continuous flooding and severe drought. The sesame seedling at different times of flooding treatment show a significant change like first above ground growth slows, sluggish whiten leaves, petiole thick, underground part of the taproot becomes thin, and black in color (WangMeiRong, 2012). The seed contains all essential amino acids and fatty acids. It is a good source of vitamins (pantothenic acid and vitamin E) and minerals such as calcium $(1450 \mathrm{mg} / 100 \mathrm{~g})$ and phosphorous $(570 \mathrm{mg} / 100 \mathrm{~g})$ and the seed cake is also an important nutritious livestock feed (Balasubramaniyan and Palaniappan, 2001). However, unfortunately its use as an oilseed crop has not been explored fully in our country (Hatam and Abbasi, 1994).

Sesame is a low water use crop and is unique in its ability to reserve late season moisture for the following crop. Planting techniques are the most important aspects of advanced production technology which not only ensures better crop establishment but also results in efficient irrigation water utilization, especially when the crop is sown on ridges or beds (Asghar et. al., 2003). Higher water use efficiency was

\footnotetext{
*Corresponding author: E-mail: akramcp@gmail.com
} 
recorded with the planting techniques of seed spreading augmented with furrows and that of bed planting as compared to the flat planting technique (Aggarwal and Goswami, 2003; Amin et. al., 2006; Waraich, 2006). In addition, improvement in water use efficiency is also endorsed due to better availability of plant nutrients, lower weed density in ridge sowing, and ultimately an enhanced final crop yield in irrigation under seed spreading augmented with furrows planting method as compared to the flat planting (Nasrullah et. al., 2009).

Sowing of sesame on beds and also on ridges produce higher number of capsules per plant and more seed weight, because plants on beds have suitable spacing for light penetration and this arrangement may also reduce competition among the plants. Sesame does not like water at the beginning because it compacts the soil and reduces oxygen to the roots, and the potential of making the roots lazy and not penetrating as deep (El-Serogy et. al., 1997; Weiss, 2000).

Keeping in view the above facts, traditional flooding method of irrigation creates waterlogged condition resulting in restricted growth and low productivity. Planting techniques are considered an important aspect of advanced production technology which not only ensures better crop establishment but also results in water saving when the crop is sown on ridges or beds. The present study was conducted to evaluate the maximum potential of sesame crop and to avoid water logging stress by adopting new suitable planting technique instead of conventional flat field planting.

\section{Materials and methods}

The study was carried out at research area of the Agronomic Research Station, Bahawalpur during the year 2010 and 2011. The experiment comprised of three planting techniques viz. $\mathrm{P}_{1}$ (flat sowing with $45 \mathrm{~cm}$ apart rows), $\mathrm{P}_{2}$ (ridge sowing with $45 \mathrm{~cm}$ apart), $\mathrm{P}_{3}$ (bed sowing with $60 / 30 \mathrm{~cm}$ i.e. $60 \mathrm{~cm}$ wide beds with $30 \mathrm{~cm}$ furrow between the beds). Sesame varieties (TH-3 and TH-6) were sown during the year 2010 and 2011 on a well prepared seedbed. The experiment was laid out in Randomized Complete Block Design (RCBD) with split plot arrangement and there were three replications. Planting methods were kept in main plots while sesame varieties were kept in sub plots. The net plot size was $3.15 \mathrm{~m}$ $\times 9 \mathrm{~m}$ and seed rate was $4 \mathrm{~kg} \mathrm{ha}^{-1}$. Fertilizers (nitrogen and phosphorous) were applied at the rate of $60 \mathrm{~kg} \mathrm{ha}^{-1}$ in the form of Urea and Tripple Super Phosphate as a basal dose. Thinning was done after two weeks of sowing to maintain plant to plant distance. First irrigation was given after 25 days of sowing while subsequent irrigations were applied according to the need of the crop. Hoeing was done twice to keep the crop free from weeds. All other agronomic practices were kept constant and uniform for all the treatments.

\section{Procedures for data collection}

Data for yield parameters such as number of capsules plant ${ }^{-1}$, number of grains capsule ${ }^{-1}$, 1000-grains weight, grain yield and plant wilting percentage were recorded during the course of studies. The detail is under:

\section{Number of capsules plant ${ }^{1}$}

Number of capsules per plant were counted of five selected plants in each plot and then averaged as per plant.

\section{Number of grains capsule $e^{-1}$}

Number of grains per capsule were recorded by counting number of grains of 10 pods/ capsules from each plot and then averaged as grains per pod.

1000-grains weight

Three samples of 1000-grains from each plot were counted and weighed and then averaged.

\section{Grain yield}

The total grain yield of net plot was taken, weighed and then calculated on per hectare basis.

\section{Plant wilting percentage}

Three samples of per square meter area from each plot were taken and number of total plants $\mathrm{m}^{-2}$ and number of wilted plants $\mathrm{m}^{-2}$ were counted then averaged and then percentage was calculated.

\section{Statistical analysis}

The data collected were transferred to the computer for analysis. Analysis of variance (ANOVA) was accomplished by using statisties computer program at 5\% level of probability.

\section{Results and discussion}

Number of pods per plant: The data given in Table I revealed that the number of pods plant $^{-1}$ was significantly affected by different planting methods. Maximum number of pods plant ${ }^{-1}$ (83.32) was produced in $\mathrm{P}_{3}$ (ridge sowing), followed by $\mathrm{P}_{2}$ (bed sowing) which produced 82.6 pods per plant. Minimum number of pods plant ${ }^{-1}$ (79.6) was recorded in $P_{1}$ (flat sowing) treatment. Almost similar trend was noted during the second year of study, i.e. more pod formation under bed and ridge planting while lower at flat planting. 
Table I. Effect of different planting techniques on number of pods per plant, number of grains per pod and 1000 grain weight (g) of two sesame varieties

\begin{tabular}{ccccccc}
\hline & \multicolumn{2}{c}{ Number of pods per plant } & \multicolumn{2}{c}{ Number of grains per pod } & \multicolumn{2}{c}{1000 -grain weight $(\mathrm{g})$} \\
\hline Treatments & 2010 & 2011 & 2010 & 2011 & 2010 & 2011 \\
Varieties $(\mathrm{V})$ & & & & & \\
$\mathrm{V}_{1}$ & $103.48 \mathrm{a}$ & $103.30 \mathrm{a}$ & $26.80 \mathrm{a}$ & $29.00 \mathrm{~b}$ & 2.60 & $2.70 \mathrm{~b}$ \\
$\mathrm{~V}_{2}$ & $60.22 \mathrm{~b}$ & $60.30 \mathrm{~b}$ & $49.60 \mathrm{~b}$ & $48.30 \mathrm{a}$ & 3.40 & $3.20 \mathrm{a}$ \\
LSD at 5\% & 9.37 & 2.08 & 5.06 & 1.27 & $\mathrm{NS}$ & 0.23 \\
Planting & & & & & & \\
techniques (P) & & & & & & \\
$\mathrm{P}_{1}$ & $79.63 \mathrm{~b}$ & $82.20 \mathrm{a}$ & $35.70 \mathrm{c}$ & $36.30 \mathrm{~b}$ & $1.80 \mathrm{~b}$ & $1.70 \mathrm{~b}$ \\
$\mathrm{P}_{2}$ & $82.60 \mathrm{ab}$ & $84.50 \mathrm{a}$ & $40.30 \mathrm{a}$ & $40.00 \mathrm{a}$ & $3.50 \mathrm{a}$ & $3.60 \mathrm{a}$ \\
$\mathrm{P}_{3}$ & $83.32 \mathrm{a}$ & $83.00 \mathrm{a}$ & $38.50 \mathrm{~b}$ & $39.80 \mathrm{a}$ & $3.60 \mathrm{a}$ & $3.60 \mathrm{a}$ \\
LSD at 5\% & 3.16 & 5.86 & 1.17 & 1.51 & 1.33 & 0.22 \\
$\mathrm{~V}_{1} \mathrm{P}_{1}$ & $100.60 \mathrm{a}$ & $100.00 \mathrm{a}$ & $25.00 \mathrm{e}$ & $28.00 \mathrm{c}$ & $1.70 \mathrm{~b}$ & $1.70 \mathrm{c}$ \\
$\mathrm{V}_{1} \mathrm{P}_{2}$ & $104.80 \mathrm{a}$ & $106.70 \mathrm{a}$ & $28.30 \mathrm{~d}$ & $29.90 \mathrm{c}$ & $2.90 \mathrm{a}$ & $3.20 \mathrm{~b}$ \\
$\mathrm{~V}_{1} \mathrm{P}_{3}$ & $105.00 \mathrm{a}$ & $107.70 \mathrm{a}$ & $27.00 \mathrm{~d}$ & $29.20 \mathrm{c}$ & $3.00 \mathrm{a}$ & $3.20 \mathrm{~b}$ \\
$\mathrm{~V}_{2} \mathrm{P}_{1}$ & $58.70 \mathrm{~b}$ & $60.30 \mathrm{~b}$ & $46.30 \mathrm{c}$ & $44.70 \mathrm{~b}$ & $1.80 \mathrm{~b}$ & $1.70 \mathrm{c}$ \\
$\mathrm{V}_{2} \mathrm{P}_{2}$ & $60.40 \mathrm{~b}$ & & & $50.00 \mathrm{a}$ & $4.20 \mathrm{a}$ & $4.00 \mathrm{a}$ \\
$\mathrm{V}_{2} \mathrm{P}_{3}$ & $61.6 \mathrm{~b}$ & $58.30 \mathrm{~b}$ & $50.00 \mathrm{~b}$ & $50.30 \mathrm{a}$ & $4.10 \mathrm{a}$ & $4.00 \mathrm{a}$ \\
LSD at $5 \%$ & 4.47 & 8.29 & 1.66 & 2.13 & 0.471 & 0.32 \\
\hline
\end{tabular}

Mean sharing the common letters in a column do not differ significantly from each other at $\mathrm{p} . \quad 0.05, \mathrm{NS}=$ Non significant V1 = TH-3, V2 = TH-6, P1 = Flat sowing with $45 \mathrm{~cm}$ apart rows, P2 = Ridge sowing with $45 \mathrm{~cm}$ apart, P3 = Bed sowing with $60 / 30 \mathrm{~cm}$ i.e. $60 \mathrm{~cm}$ wide beds with $30 \mathrm{~cm}$ furrow.

It can be attributed towards more efficient nutrient up-take in $\mathrm{P}_{2}$ (ridge sowing) and $\mathrm{P}_{3}$ (bed sowing) resulting in enhanced vegetative growth, leading to better fruiting. These results are in line with those reported by Asghar et al. (2003), Amin et al. (2006); Aggarwal and Goswami (2003); Waraich (2006) and El-Serogy et al. (1997) who reported that higher seed yield in bed sowing may be attributed to more number of capsules produced by plants sown on beds.

As far as the varieties are concerned, $\mathrm{V}_{1}(\mathrm{TH}-3)$ produced more number of pods per plant with the same trend during both the years. Since the interaction of varieties and planting methods showed statistically at par response under different planting methods, hence this may be attributed to the enhanced genetic ability of branching, the more the branches; the more are the pods per plant. The planting methods may affect the branching attitude of a variety since it provide better aeration and ample sunlight penetration as the researchers say that direct sunlight has a tremendous effect on the amount of branching (Langham, 2008).

\section{Number of grains per pod}

The data given in Table I represented that the number of grain pod $^{-1}$ was significantly affected by different varying planting patterns. Maximum number of grain $\operatorname{pod}^{-1}$ (40.3 and 38.5) were produced in $\mathrm{P}_{2}$ (bed sowing) and $\mathrm{P}_{3}$ (ridge sowing) and minimum number of grain pod ${ }^{-1}(35.7)$ was recorded in $\mathrm{P}_{1}$ (flat sowing) treatment having similarity of trend in grain per pod during the following year of study. This may be attributed to the fact that plants on beds have suitable spacing for light penetration and this arrangement may also reduce competition among plants and obtained highest number of grains pod $^{-1}$ of sesame by sowing the crop on ridges and beds as other researchers have reported increase in other yield components (Langham, 2008). As far as the varieties are concerned, $V_{2}$ (TH-6) produced more number of grains per pod with the similar trend during both the years. This may be attributed to the enhanced genetic potential of crop varieties as well as better environment of root development for better nutrient uptake and better aeration and light penetration for better growth and development under ridge and bed sowing methods. 


\section{0-grain weight (g)}

It was revealed that 1000 -grain weight was significantly affected by bed and ridge sowing (Table I). The highest 1000 -grain weight ( 3.6 and $3.5 \mathrm{~g}$ ) was obtained in ridge and bed sowing. The lowest 1000 -grain weight $(1.8 \mathrm{~g})$ was obtained when crop was sown on flat field ( $40 \mathrm{~cm}$ apart rows) with similar trend during both the years. These results are similar to those of Abuja et al. (1971); El-Serogy et al. (1997) as well as better environment of root development for better nutrient uptake and better aeration and light penetration for better growth, development and better translocation photosynthates towards fruiting sites under ridge and bed sowing methods (Asghar et al. 2003). The interaction also presented the similar trend of producing more fruiting or heavier grains under ridge and beds sowing conditions as compared to conventional flat planting.

Table II. Effect of different planting techniques on plants wilting (\%) and grain yield (kg ha-1) of two sesame varieties

\begin{tabular}{|c|c|c|c|c|}
\hline & Plants & $g(\%)$ & Grain yield & $\left(\mathrm{kg} \mathrm{ha}^{-1}\right)$ \\
\hline Treatments & 2010 & 2011 & 2010 & 2011 \\
\hline \multicolumn{5}{|l|}{ Varieties (V) } \\
\hline $\mathrm{V}_{1}$ & $25.60 \mathrm{a}$ & $25.10 \mathrm{~b}$ & 665.80 & $715.00 \mathrm{a}$ \\
\hline $\mathrm{V}_{2}$ & $30.50 \mathrm{a}$ & $32.20 \mathrm{a}$ & 660.60 & $635.80 \mathrm{~b}$ \\
\hline LSD at $5 \%$ & 5.76 & 5.90 & NS & 56.98 \\
\hline \multicolumn{5}{|l|}{$\begin{array}{l}\text { Planting } \\
\text { techniques }(\mathrm{P})\end{array}$} \\
\hline $\mathrm{P}_{1}$ & $66.90 \mathrm{a}$ & $63.50 \mathrm{a}$ & $372.70 \mathrm{c}$ & $324.70 \mathrm{~b}$ \\
\hline $\mathrm{P}_{2}$ & $8.40 \mathrm{~b}$ & $13.10 \mathrm{~b}$ & $851.30 \mathrm{a}$ & $833.50 \mathrm{a}$ \\
\hline$P_{3}$ & $8.90 \mathrm{~b}$ & $9.78 \mathrm{~b}$ & $755.30 \mathrm{~b}$ & $867.00 \mathrm{a}$ \\
\hline LSD at $5 \%$ & 3.23 & 4.51 & 35.25 & 56.78 \\
\hline $\mathrm{V}_{1} \mathrm{P}_{1}$ & $61.60 \mathrm{~b}$ & $54.20 \mathrm{~b}$ & $375.70 \mathrm{c}$ & $363.30 \mathrm{c}$ \\
\hline $\mathrm{V}_{1} \mathrm{P}_{2}$ & $6.90 \mathrm{c}$ & $11.50 \mathrm{c}$ & $864.00 \mathrm{a}$ & $883.00 \mathrm{a}$ \\
\hline $\mathrm{V}_{1} \mathrm{P}_{3}$ & $8.20 \mathrm{c}$ & $9.70 \mathrm{c}$ & $757.70 \mathrm{~b}$ & $898.70 \mathrm{a}$ \\
\hline $\mathrm{V}_{2} \mathrm{P}_{1}$ & $72.20 \mathrm{a}$ & $72.70 \mathrm{a}$ & $369.70 \mathrm{c}$ & $286.00 \mathrm{c}$ \\
\hline $\mathrm{V}_{2} \mathrm{P}_{2}$ & $9.90 \mathrm{c}$ & $14.70 \mathrm{c}$ & $838.70 \mathrm{a}$ & $784.00 \mathrm{~b}$ \\
\hline $\mathrm{V}_{2} \mathrm{P}_{3}$ & $9.50 \mathrm{c}$ & $9.90 \mathrm{c}$ & $753.00 \mathrm{~b}$ & $835.30 \mathrm{ab}$ \\
\hline LSD at $5 \%$ & 4.57 & 6.38 & 49.85 & 80.30 \\
\hline
\end{tabular}

Mean sharing the common letters in a column do not differ significantly from each other at p. 0.05 , NS $=$ Non significant. $\mathrm{V}_{1}=\mathrm{TH}-3, \mathrm{~V}_{2}=\mathrm{TH}-6, \mathrm{P}_{1}=$ Flat sowing with $45 \mathrm{~cm}$ apart rows, $\mathrm{P}_{2}=$ Ridge sowing with $45 \mathrm{~cm}$ apart, $\mathrm{P}_{3}=$ Bed sowing with $60 / 30 \mathrm{~cm}$ i.e. $60 \mathrm{~cm}$ wide beds with $30 \mathrm{~cm}$ furrow

and Asghar et al. (2003) who reported that sowing sesame on beds of $50 \mathrm{~cm}$ width gave highest value for number of capsules plant ${ }^{-1}$ and highest 1000 -grain weight of sesame by sowing the crop on ridges owing to the reason that plants on beds have suitable spacing for light penetration and having reduced competition among plants.

As far as the varieties are concerned, during both the years, $\mathrm{V}_{2}$ (TH-6) produced heavier grains as compared to $\mathrm{V}_{1}$ (TH-3) and differ significantly during the year 2011. This may be attributed to the enhanced genetic potential of crop varieties

\section{Plant wilting (\%)}

It was revealed that plant wilting (\%) was significantly affected by bed and ridge sowing. The lowest plant wilting ( 8.4 and $8.9 \%$ ) was obtained in ridge and bed sowing, respectively. The highest plant wilting (\%) was recorded when crop was planted on flat field (66.9\%). This was due to the fact that there was no more water logged condition in the root zone of the crop under ridge and bed conditions as well as more availability of nutrients with irrigation water (Amin et al. 2006). Similar trend was recorded during the second year of study (Table II). 


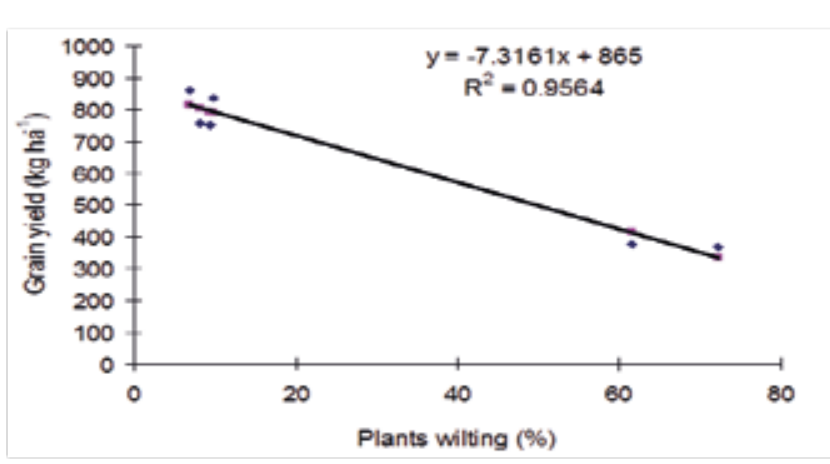

Fig. 1. Regression analysis between plants wilting and grain yield during year 2010

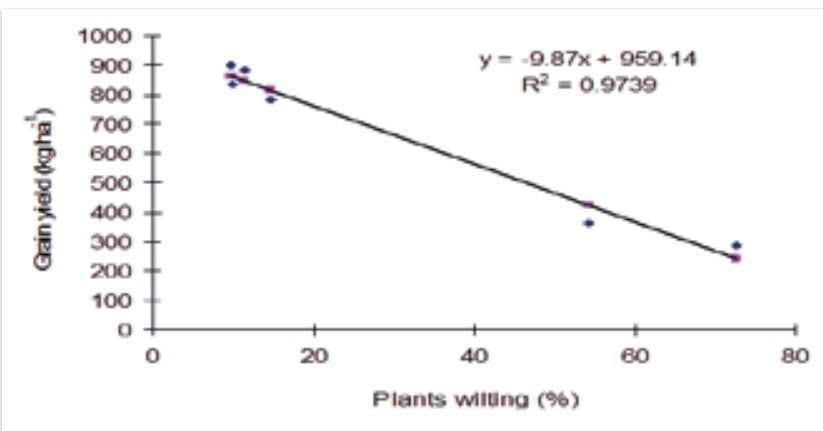

Fig. 2. Regression analysis between plants wilting and grain yield during year 2011

The varieties showed almost non significant response but with greater figures of wilting $\%$ in $\mathrm{V}_{2}$ (TH-6). The results of 2011 were statistically significant with higher wilting percentage in $\mathrm{V}_{2}$. The interaction also presented the similar trend of producing less wilting of plants under ridge and beds sowing conditions as compared to conventional flat planting (Table II).

\section{Grain yield}

The results showed that maximum grain yield $\left(851.3 \mathrm{~kg} \mathrm{ha}^{-1}\right)$ was obtained by ridge sowing followed by bed sowing that gave $755.3 \mathrm{~kg} \mathrm{ha}^{-1}$ grain yield during 2010 . It was statistically at par during 2011 with 833.5 and $867.0 \mathrm{~kg} \mathrm{ha}^{-1}$, respectively, proving the superiority of ridge and bed over flat/conventional planting. Minimum grain yield (372.7 and $324.7 \mathrm{~kg} \mathrm{ha}^{-1}$ ) was produced in flat sowing (40 $\mathrm{cm}$ apart rows) during 2010 and 2011. However, both the varieties gave statistically similar yields during 2010 but $\mathrm{V}_{1}$ (TH3) produced more grain yield (715.0 $\mathrm{kg} \mathrm{ha}^{-1}$ ) than $\mathrm{V}_{2}\left(635.8 \mathrm{~kg} \mathrm{ha}^{-1}\right)$ during 2011 (Table II). Higher grain yield in bed and ridge sowing may be attributed to more number of capsules produced per plant sown on beds and ridges. These results are in line with the findings of Asghar et al., (2003); Ahmad et al., (2010); Amin et al., (2006); Waraich (2006); Aggarwal and Goswami (2003) who stated that in case of planting geometry, maximum seed yield was obtained by bed sowing $(50 / 30 \mathrm{~cm})$, followed by ridge sowing (40 cm apart) that gave lower seed yield. The growth and seed yield of sesame are adversely affected by continuous flooding and severe drought (Mensah et al. 2006). Therefore, the selection of suitable varieties, appropriate spacing and a proper planting method are of paramount importance for increasing the productivity of the sesame crop (Panneerselvam et al., 2005). Noor et al., (2014) also screened out different french bean genotypes and concluded that BARI bush bean -1 showed highest yield and superior quality of french bean.

\section{Regression and correlation analysis}

In Figure 1 and 2 the relationship between plants wilting percentage and grain yield is presented. Regression between Plant wilting and grain yield is highly significant during both the year (2010 and 2011). Correlation analysis (Table III) indicates that there is highly significant negative correlation between number of pods per plant and number of grain per pod during both year 2010 and 2011. It has also been observed that

Table III. Correlations coefficients (r) of different yield parameters and wilting \% characterizing sesame varieties grown under planting techniques

\begin{tabular}{|c|c|c|c|c|c|c|c|c|c|}
\hline \multirow[b]{2}{*}{ Parameters } & \multicolumn{5}{|c|}{ Year 2010} & \multicolumn{4}{|c|}{ Year 2011} \\
\hline & $\begin{array}{r}\text { Numbe } \\
\text { pe }\end{array}$ & $\begin{array}{l}\text { r of grains } \\
\text { er pod }\end{array}$ & $\begin{array}{l}1000 \text { - grain } \\
\text { weight }\end{array}$ & Wilting \% & $\begin{array}{l}\text { Grain } \\
\text { yield }\end{array}$ & $\begin{array}{l}\text { Number of grains } \\
\text { per pod }\end{array}$ & $\begin{array}{l}\text { 1000- grain } \\
\text { weight }\end{array}$ & Wilting \% & Grain yield \\
\hline $\begin{array}{l}\text { Number of } \\
\text { per plant }\end{array}$ & pods & $-0.98 * *$ & $-0.41^{\mathrm{NS}}$ & $-0.10^{\mathrm{NS}}$ & $0.03^{\mathrm{NS}}$ & $-0.97 * *$ & $-0.22 \mathrm{NS}$ & $-0.20^{\mathrm{NS}}$ & $0.23^{\mathrm{NS}}$ \\
\hline $\begin{array}{l}\text { Number of } \\
\text { per pod }\end{array}$ & grains & - & $0.56^{\mathrm{NS}}$ & $-0.07^{\mathrm{NS}}$ & $0.13^{\mathrm{NS}}$ & 5 & $0.45^{\mathrm{NS}}$ & $-0.04^{\mathrm{NS}}$ & $0.01 \mathrm{NS}$ \\
\hline 1000 -grai & weigh & - & - & $0.84 * *$ & $0.83 * *$ & - & - & $-0.91 * *$ & $0.88 * *$ \\
\hline Wilting \% & & - & - & - & $-0.98 * *$ & - & - & - & $-0.99 * *$ \\
\hline
\end{tabular}

Note: $*$ and $* *$ _ significant at 0.05 and 0.01 levels, respectively; NS_-non significant. 
there is significant negative correlation among 1000 grain weight, wilting $\%$ age and grain yield. The correlation analysis among number of pods per plant, number of grain per pod and grain yield are non significant (Table III).

\section{Conclusion}

It can be concluded that sesame crop should be sown on beds and ridges to obtain maximum return per unit area. Because higher water use and nutrient uptake efficiency was recorded with the planting techniques of ridge planting and that of bed planting as compared to the flat planting technique. A raised bed may provide a storage bank of moisture until temperatures rise to sufficient levels to plant and also provide a way for excess moisture to be drained from the seed zone. This allows better aeration of the soil and reduces potential of seedling diseases. Hence it is concluded that the water lodging in the root zone can successfully be avoided by planting sesame on beds or ridges and optimum grain yields can be obtained by this technology.

\section{References}

Abuja KI, Sekhon JS and Gupta TR (1971), Effect of some cultural treatment on the yield and chemical composition of sesame (Sesamum mindicum L.). Indian Journal of Agronomy, 16: 445-448.

Aggarwal P and Goswami B (2003), Bed planting system for increasing water use efficiency of wheat grown on Inceptisol (Typic Ustochrept). Indian Journal of Agricultural Sciences, 73: 422-25.

Ahmad M, Ghafoor A, Asif M and Farid HU (2010), Effect of irrigation techniques on wheat production and water saving in soils. Soil and Environ. 29: 69-72.

Amin M, Razzaq A, Rehmatullah and Ramzan M (2006), Effect of planting methods, seed density and nitrogen-phosphorus (NP) fertilizer levels on sweet corn (Zea mays L.). Journal of Research Science, 17: 83-89.

Asghar MM, Saleem MF, Cheema MA and Ahmed S (2003), Influence of different nitrogen levels on productivity of sesame (Sesamum indicum L.) under varying planting patterns. International journal of agriculture \& biology, 1560-8530/ 05(4) pp- 490-492 http://www.ijab.org.

Balasubramaniyan P and Palaniappan SP (2001), Field Crops: An overview. In: Principles and Practices of Agronomy. p- 47. Agrobios, India.

El-Serogy ST, El-Eman MA and Sorour WAI (1997), The performance of two sesame varieties under different sowing method in two locations. Annals of Agricultural Science, 42: 355-4.
Hatam M and Abbasi GQ (1994), Oil Seed Crops. In: Crop Production pp: 358-7. National Book Foundation, Islamabad, Pakistan.

Langham DR (2008), Growth and Development of Sesame (May). The American Sesame Growers Association, website at: www.sesamegrowers.org.

Mensah JK, Obadoni BO, Eruotor PG and Onome-Irieguna F (2006), Simulated flooding and drought effects on germination, growth, and yield parameters of sesame (Sesamum indicum L.). African Journal of Biotechnology, 5: 1249-1253, 3 Available online at http://www.academicjournals.org/AJB.

Nasrullah HM, Cheema MS and Akhtar M (2009) Efficiency of different dry sowing methods to enhance wheat yield under cotton-wheat cropping system. Intl. Conference on Sustainable Food Grain production-Challenges and Opportunities. Oct. 26-27, Univ. Agric. Faisalabad. Pakistan. p-66-12.

Noor F, Hossain F and Ara U (2014), Screening of french bean (Phaseolus vulgaris L.) genotypes for high yield potential. Bangladesh J. Sci. Ind. Res. 49: 227-232.

Panneerselvam PR, Manuel I and Jahur HB (2005), Evaluation of Different Varieties of Sesame with Different Spacing under Rice Fallow Conditions. Sesame and Safflower Newsletter 20-2005. Department of Agronomy, Annamalai University, Annamalai Nagar - 608 002, Tamil Nadu, India.).

Smith DT, James G, Amanda A and McCallum (2000), Crop Profile for Sesame in United States Texas Agricultural Experiment Station, College Station and Yoakum prepared. p-116.

Waraich EA (2006), Crop management strategies to improve water use efficiency in irrigated wheat. Ph.D Thesis, Dept Agron. Univ. Agric. Faisalabad. Pakistan. p- 3-19

Wang MR (2012), Effects of water logging stress on physiological features and differential expression of protein of Sesamum indicum seeding. pp- 5-9.

Weiss EA (2000), Oil seed crops. 2nd ed. Oxford: Blackwell Science. Oxford, U.K.

Received: 21 May 2015; Revised: 22 July 2015;

Accepted: 19 October 2015. 